\title{
PENERAPAN LEAN MANUFACTURING UNTUK MEMINIMASI WASTE WAITING PADA PROSES PRODUKSI HANGER SAMPLE DI CV. ABC OFFSET
}

\section{IMPLEMENTATION OF LEAN MANUFACTURING TO MINIMIZE WAITING WASTE ON HANGER SAMPLE PRODUCTION PROCESS AT CV. ABC OFFSET}

\author{
${ }^{1}$ Ireyna Nissa Octaviany, ${ }^{2}$ Agus Alex Yanuar, ${ }^{3}$ Meldi Rendra \\ 1,2,3Program Studi Teknik Industri, Fakultas Rekayasa Industri, Telkom University \\ 1ireynano@student.telkomuniversity.ac.id, ${ }^{2}$ axytifri@ @elkomuniversity.ac.id, ${ }^{3}$ meldirendra@telkomuniversity.ac.id
}

\begin{abstract}
Abstrak-CV. ABC Offset adalah sebuah perusahaan yang bergerak dibidang percetakan dengan sistem make to order, dimana salah satu produk yang konsisten dipesan adalah hanger sample yang dipesan oleh perusahaan tekstil. Pada bulan Januari, Februari, Juni, Agustus, dan Oktober produksi tidak mencapai jumlah permintaan $(73 \%, 80 \%, 92 \%, 71 \%$, dan $50 \%)$. Hal tersebu disebabkan oleh permasalahan yang menghambat jalannya proses produksi. Melalui hasil observasi lapangan dan hasil pengolahan kuesioner, diketahui bahwa salah satu waste dominan yang terjadi pada proses pembuatan hanger sample adalah waste waiting. Upaya meminimasi waste waiting pada penelitian ini dilakukan dengan menggunakan pendekatan lean manufacturing. Penelitian diawali dengan melakukan pengumpulan data seperti alur proses produksi, waktu siklus, kuesioner, data permintaan, data produksi, data jumlah operator, dan data jam kerja. Selanjutnya dilakukan pemetaan aliran proses saat ini dengan menggunakan value stream mapping (VSM) dan process activity mapping (PAM) current state. Tahap berikutnya adalah mengidentifikasi akar penyebab waste waiting dengan menggunakan diagram fishbone, diagram pareto, dan 5 whys. Setelah diketahui akar penyebabnya, dibuat usulan perbaikan guna meminimasi waste waiting dimana bidang ilmu yang akan digunakan adalah perancangan tata letak fasilitas. Setelah itu value stream mapping (VSM) future state dibuat untuk memetakan perbaikan yang akan diusulkan.
\end{abstract}

Kata kunci: lean manufacturing, value stream mapping, process activity mapping, waste waiting, perancangan tata letak fasilitas

\begin{abstract}
CV. ABC Offset is a printing company with make to order system, which hanger sample is a product being ordered constantly by textile companies. In January, February, June, August and October the amount production did not reach the demand $(73 \%, 80 \%, 92 \%, 71 \%$, dan $50 \%)$. It was due to the problem that inhibit production. Based on field observation and questionnaire data processing, it was known that one of dominant waste occured in the production process of hanger sample was waste waiting. Effort to minimize the waste in this research will be done with lean manufacturing approach. The research will be started by collecting data, such as production process flow, cycle time, questionnaire, demand data, production data, number of operators and work hour. After that, value stream mapping (VSM) and process activity mapping (PAM) current state will be made for mapping the process flow. The next step is identifying the root cause of waste waiting using fishbone diagram, pareto diagram and 5 whys. After the root cause is known the proposed improvement is made to minimize waste waiting where the subject that will be used is facility layout planning. Then, value stream mapping (VSM) future state will be made for mapping the flow process and improvements that will be proposed.
\end{abstract}

Keywords: lean manufacturing, value stream mapping, process activity mapping, waste waiting, facility layout planning

\section{PENDAHULUAN}

CV. ABC Offset adalah sebuah perusahaan yang bergerak dibidang percetakan dan umum yang menggunakan sistem make to order, dimana proses produksi akan berjalan setelah pesanan pelanggan diterima. Adapun salah satu jenis produk yang sering dipesan, yaitu hanger sample yang dipesan oleh perusahaan tekstil. Pada CV. ABC Offset terdapat bagian-bagian dalam alur proses produksi yang dibagi kedalam beberapa stasiun kerja, yaitu: stasiun cutting, stasiun cetak, stasiun foil, stasiun pemberian lem, stasiun penempelan, stasiun press, stasiun tag pin and rail, stasiun pemasangan gantungan \& paku, dan stasiun packing. Alur proses produksi hanger sample ditunjukkan pada Gambar 1.

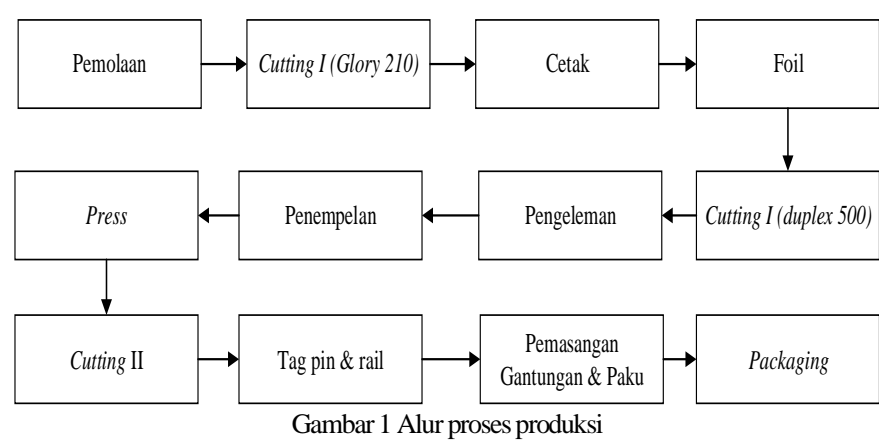

Melalui data permintaan dan realisasi produksi untuk hanger sample yang diperoleh dari perusahaan, maka dapat dilakukan analisis apakah terdapat permasalahan dalam proses produksi. Tabel I menunjukkan data permintaan dan realisasi produksi hanger sample periode Januari 2016 hingga Oktober 2016.

Dari Tabel I, dapat diketahui bahwa pada periode Januari, Februari, Juni, Agustus, dan Oktober realisasi produksi tidak memenuhi jumlah permintaan. Hal ini terjadi disebabkan oleh permasalahan yang menghambat terjadinya proses produksi. Melalui observasi lapangan, didapatkan beberapa permasalahan yang terjadi pada proses pembuatan hanger sample, yaitu waktu setup mesin cetak 
yang terlalu lama karena proses penggantian warna, proses selanjutnya belum bisa berjalan karena adanya bahan baku yang belum siap pada stasiun pengeleman dan stasiun cutting, material menunggu pada stasiun press karena kurangnya alat, dan tata letak fasilitas yang kurang efektif karena stasiun kerja yang berurutan letaknya berjauhan. Berdasarkan hasil observasi lapangan dapat diketahui bahwa dugaan waste utama yang terjadi adalah waste waiting pada stasiun pengeleman, cutting, press, dan stasiun cetak. Waste (pemborosan) merupakan aktivitas yang tidak memberikan nilai tambah [1].

TABEL I

DATA PERMINTAANDAN REALISASI HANGER SAMPLE PERIODE JANUARI-OKTOBER 2016

\begin{tabular}{|l|r|r|r|}
\hline \multicolumn{1}{|c|}{ Periode } & Permintaan & Realisasi & Ketercapaian \\
\hline Januari & 7500 & 5500 & $73 \%$ \\
\hline Februari & 5000 & 4000 & $80 \%$ \\
\hline Maret & 5000 & 5000 & $100 \%$ \\
\hline April & 3000 & 3000 & $100 \%$ \\
\hline Mei & 3000 & 3000 & $100 \%$ \\
\hline Juni & 6000 & 5500 & $92 \%$ \\
\hline Juli & 2000 & 2000 & $100 \%$ \\
\hline Agustus & 7000 & 5000 & $71 \%$ \\
\hline September & 4000 & 4000 & $100 \%$ \\
\hline Oktober & 3000 & 1500 & $50 \%$ \\
\hline
\end{tabular}

Untuk memperkuat dugaan waste yang terjadi pada proses pembuatan hanger sample, maka dilakukan penyebaran kuesioner kepada kepala produksi dan sebelas operator yang mengerjakan produksi hanger sample. Kuesioner yang digunakan berisi beberapa pertanyaan terkait 9 waste yang disingkat menjadi E-DOWNTIME, yaitu Environmental, Health and Safety (EHS), Defects, Overproduction, Waiting, Not Utilizing Employees Knowledge, Skills and Abilites, Transportation, Inventories, Motion, dan Excess Processing [2], [3]. Berdasarkan hasil pengolahan kuesioner tersebut, didapatkan persentase waste yang terjadi pada proses pembuatan hanger sample yang ditunjukkan pada Gambar 2.

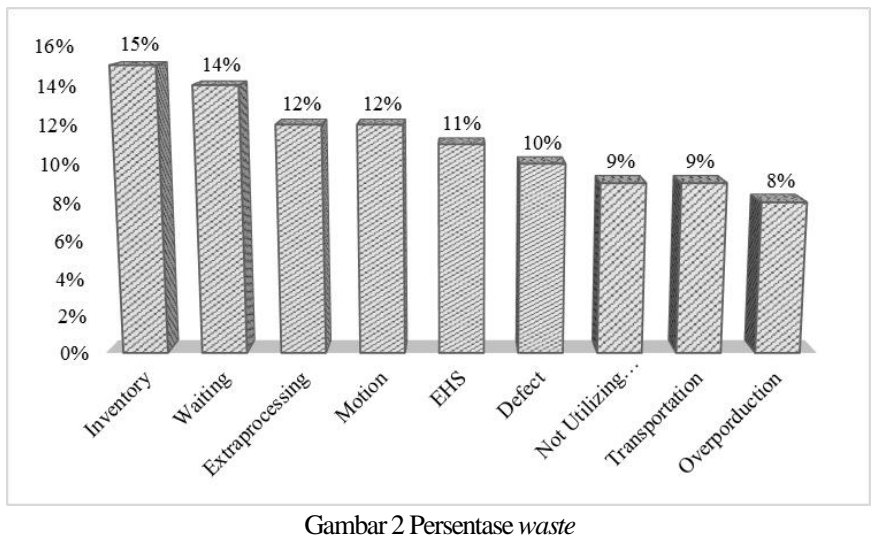

Melalui hasil observasi lapangan, dapat diketahui bahwa dugaan waste yang terjadi pada proses pembuatan hanger sample adalah waste waiting dan dari hasil pengolahan kuesioner, dapat diketahui bahwa jenis waste dengan dua persentase terbesar adalah inventory
(15\%) dan waiting (14\%). Oleh karena itu, waste waiting akan dijadikan fokus penelitian. Waste waiting merupakan pemborosan yang terjadi karena adanya proses menunggu, seperti waktu tunggu orang, waktu tunggu mesin, atau waktu tunggu material untuk diproses [2].

Untuk dapat meminimasi waste waiting, maka digunakan konsep lean manufacturing. Lean merupakan proses mengidentifkasi dan mengeliminasi pemborosan yang terjadi pada perusahaan [2], dimana pendekatan lean berfokus pada peningkatan terus-menerus nilai pelanggan melalui identifikasi dan eliminasi aktivitas-aktivitas tidak bernilai tambah yang merupakan pemborosan (waste) [3]

\section{HASIL DAN ANALISIS}

\section{A. Value Stream Mapping current state}

Value stream mapping (VSM) merupakan salah satu alat Lean Six Sigma (LSS) yang digunakan untuk memetakan seluruh aktivitas (value-added \& non value-added) sepanjang value stream [2]. Melalui informasi proses produksi dan data waktu siklus yang telah diolah, maka dirancanglah value stream mapping current state untuk memetakan aliran proses produksi secara keseluruhan. Dengan value stream mapping current state, dapat ditunjukkan dengan jelas aliran informasi dan aliran material dari proses produksi hanger sample hingga sampai ke tangan konsumen [4]. Pada VSM diketahui total lead time adalah 32.744,139 detik dan total cycle time adalah 30.009,397 detik. Gambar value stream mapping current state dapat dilihat pada Lampiran.

\section{B. Process Activity Mapping current state}

Process activity mapping (PAM) merupakan salah satu alat yang dibuat untuk mengetahui aliran proses dengan lebih terperinci [5], dimana pada penelitian ini adalah aliran proses produksi hanger sample. Output dari process activity mapping yang telah dibuat adalah lead time, total value added time, total necessary non-value added time, dan total value added time, sehingga dapat diketahui aktivitas mana yang merupakan pemborosan (waste) dan harus diminimasi. Jumlah aktivitas yang terdapat pada proses pembuatan hanger sample adalah 97 aktivitas. Adapun hasil pengolahan process activity mapping current state pada pembuatan hanger sample dapat dilihat pada Tabel II.

TABEL II

HASIL PENGOLAHANPAM CURRENT STATE PADA PEMBUATAN HANGER SAMPLE

\begin{tabular}{|c|cc|}
\hline LEAD TIME & 40479.30 & detik \\
\hline TOTAL VALUE ADDED TIME & 30009.40 & detik \\
\hline \% VALUE ADDED TIME & $74 \%$ & \\
\hline $\begin{array}{c}\text { TOTAL NECESSARY NON-VALUE ADDED } \\
\text { TIME }\end{array}$ & 7854.72 & detik \\
\hline \% NECESSARY NON-VALUE ADDED TIME & $19 \%$ & \\
\hline TOTAL NON-VALUE ADDED TIME & 2615.18 & detik \\
\hline \% NON-VALUE ADDED TIME & $6 \%$ & \\
\hline
\end{tabular}

C. Identifikasi dan analisis penyebab waste waiting

1. Identifikasi dan analisis menggunakan fishbone diagram 


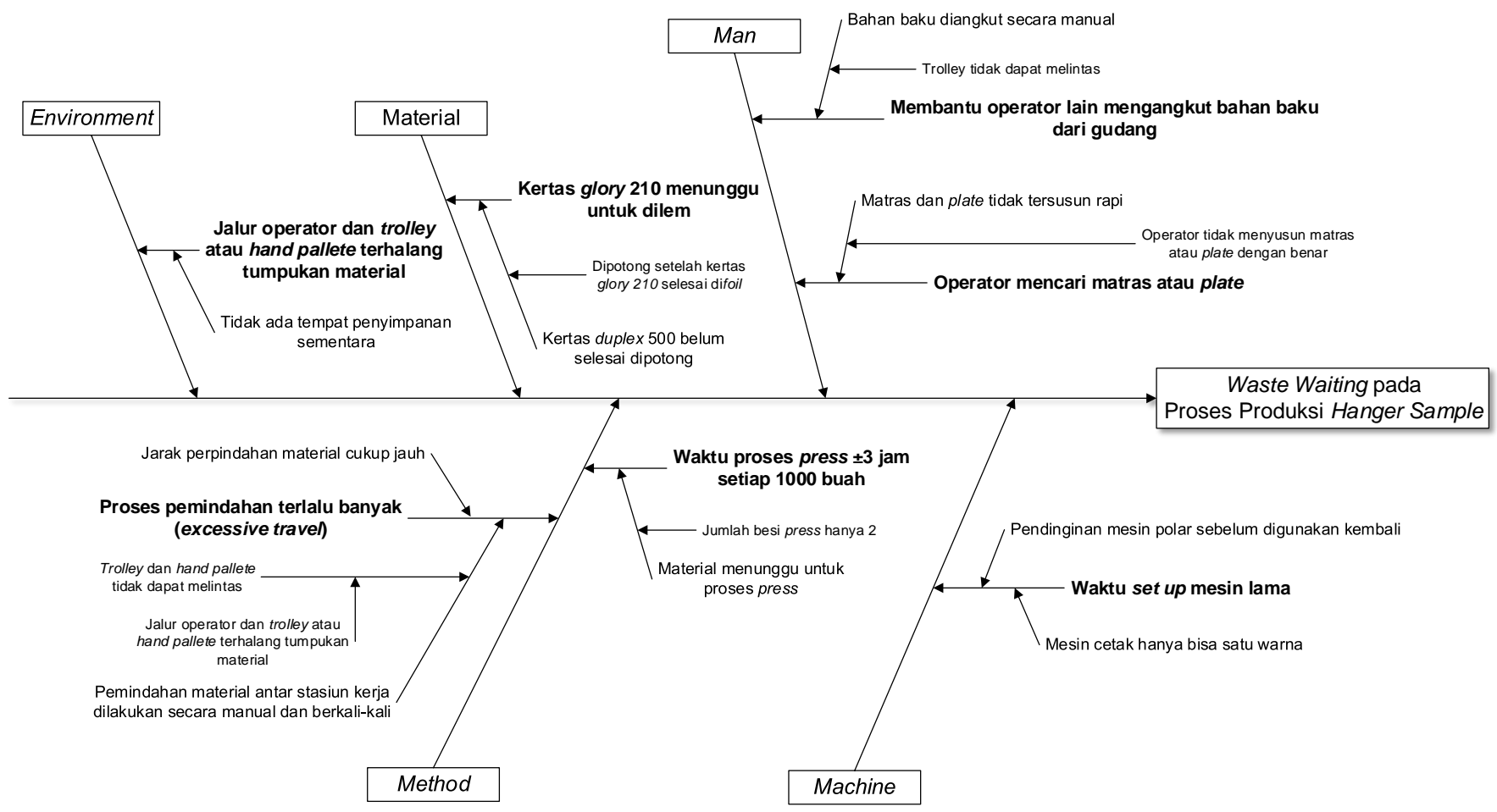

Gambar 3 Identifikasi dan analisis penyebab waste waiting dengan menggunakan fishbone diagram

Cause-and-effect diagram merupakan tampilan visual dari kemungkinan penyebab dari permasalahan atau kondisi tertentu, dimana akibat diletakkan di sisi kanan dan penyebab dibentuk seperti tulang ikan, sehingga terkadang diagram ini disebut dengan fishbone diagram [2]. Gambar 3 menunjukkan identifikasi dan analisis penyebab waste waiting dengan menggunakan fishbone diagram.

2. Pembobotan penyebab waste waiting dengan pareto diagram

Dari penyebab yang diperoleh melalui fishbone diagram, selanjutnya dilakukan pembobotan terhadap setiap penyebab berdasarkan durasi waktu dan frekuensinya per hari (diperoleh melalui wawancara dengan manajer produksi dan hasil observasi lapangan) dengan menggunakan pareto diagram. Tabel III menunjukkan durasi dan frekuensi penyebab dari waste waiting.

TABEL III

DURASIDANFREKUENSIPENYEBAB WASTE WAITING

\begin{tabular}{|c|l|r|l|}
\hline No & \multicolumn{1}{|c|}{ Penyebab Waste Waiting } & $\begin{array}{c}\text { Durasi } \\
\text { (Menit) }\end{array}$ & Frekuensi \\
\hline 1 & $\begin{array}{l}\text { Jalur operator dan trolley atau hand } \\
\text { pallete terhalang oleh tumpukan sisa } \\
\text { material }\end{array}$ & 420 & $\begin{array}{l}\text { Setiap proses } \\
\text { produksi }\end{array}$ \\
\hline 2 & $\begin{array}{l}\text { Waktu proses press } \pm 3 \text { jam setiap 1000 } \\
\text { buah }\end{array}$ & 180 & 2 kali \\
\hline 3 & Waktu set up mesin lama & 30 & 2 kali \\
\hline 4 & Kertas glory 210 menunggu untuk dilem & 18 & $\begin{array}{l}\text { Setiap proses } \\
\text { produksi }\end{array}$ \\
\hline 5 & $\begin{array}{l}\text { Operator membantu operator lain } \\
\text { mengangkut bahan baku dari gudang }\end{array}$ & 10 & $\begin{array}{l}\text { Setiap } \\
\text { perpindahan } \\
\text { stasiun kerja }\end{array}$ \\
\hline 6 & Excessive Travel & 10 & $\begin{array}{l}\text { Setiap proses } \\
\text { produksi }\end{array}$ \\
\hline 7 & Operator mencari matras atau plate & & \\
\hline
\end{tabular}

Durasi (Menit)

Adapun Gambar 4 menunjukkan pareto diagram setiap penyebab waste waiting pada proses produksi hanger sample berdasarkan durasi (menit).

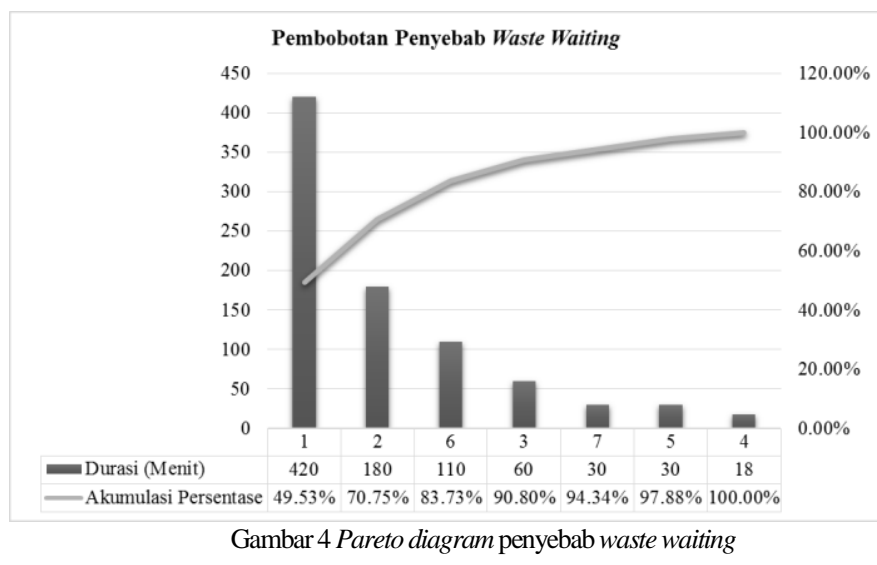

Melalui pareto diagram pada Gambar 4, dapat diketahui bahwa terdapat 3 penyebab utama terjadinya waste waiting pada proses produksi hanger sample di CV. ABC Offset. Akumulasi persentase dari ketiga faktor tersebut adalah $85,71 \%>80 \%$ dari total penyebab waste waiting sehingga dikatakan sebagai faktor yang dominan, yaitu penyebab nomor 1,2 , dan 6 .

3. Identifikasi dan analisis menggunakan 5 whys

5 whys menyebabkan adanya pertanyaan "why" atau mengapa yang berulang hingga ditemukan akar penyebab dari permasalahan yang terjadi [1]. Tabel IV menunjukkan analisis 5 whys. 
TABEL IV

ANALISIS 5 WHYS

\begin{tabular}{|c|c|c|}
\hline Faktor & Penyebab & Akar Penyebab \\
\hline \multirow{3}{*}{ Method } & $\begin{array}{l}\text { Material menunggu } \\
\text { untuk proses press }\end{array}$ & $\begin{array}{c}\text { Jumlah besi press ada } 2 \\
\text { dan hanya dapat } \\
\text { digunakan untuk } 100 \\
\text { buah }\end{array}$ \\
\hline & & $\begin{array}{c}\text { Letak antar stasiun kerja } \\
\text { tidak berurutan }\end{array}$ \\
\hline & Excessive Travel & $\begin{array}{c}\text { Jalur pada lantai } \\
\text { produksi tidak cukup } \\
\text { untuk dilalui trolley atau } \\
\text { handtruck }\end{array}$ \\
\hline Environment & $\begin{array}{c}\text { Jalur operator dan } \\
\text { trolley atau } \\
\text { handtruck terhalang } \\
\text { oleh tumpukan } \\
\text { material }\end{array}$ & $\begin{array}{c}\text { Perusahaan tidak } \\
\text { menyediakan tempat } \\
\text { penyimpanan sementara } \\
\text { material, baik bahan } \\
\text { baku maupun scrap }\end{array}$ \\
\hline
\end{tabular}

D. Usulan perbaikan

1. Perbaikan tata letak stasiun kerja

a. Membuat activity relationship diagram (ARC)

Berdasarkan studi proses manufaktur, diketahui bahwa jarak perpindahan yang jauh dapat dikurangi untuk memindahkan bahan baku, dimana alur kerja dibuat dengan mengatur urutan-urutan yang penting [6]. ARC memberikan gambaran singkat mengenai hubungan kedekatan potensial di antara area fungsional [7]. Dalam pembuatan ARC, terdapat beberapa derajat keterkaitan yang dilambangkan seperti pada Tabel V.

TABEL V

SIMBOL DERAJAT KETERKAITAN

\begin{tabular}{|c|c|c|}
\hline Simbol & Definisi & Keterangan \\
\hline $\mathrm{A}$ & $\begin{array}{c}\text { Absolutely } \\
\text { Necessary }\end{array}$ & Memiliki keterkaitan $\geq 3$ \\
\hline $\mathrm{E}$ & $\begin{array}{c}\text { Especially } \\
\text { Important }\end{array}$ & Memiliki keterkaitan $\leq 3$ \\
\hline $\mathrm{I}$ & Important & Memiliki keterkaitan $=2$ \\
\hline $\mathrm{O}$ & Ordinary & Memiliki keterkaitan $=1$ \\
\hline $\mathrm{U}$ & Unimportant & $\begin{array}{c}\text { Tidak memiliki } \\
\text { keterkaitan }\end{array}$ \\
\hline $\mathrm{X}$ & Undesirable & Diletakkan berjauhan \\
\hline
\end{tabular}

Dalam menentukan derajat keterkaitan antar stasiun kerja, maka diperlukan kriteria dari kedekatan tersebut. Kriteria kedekatan berisi alasan pendukung bagi setiap situasi agar dapat ditentukan derajat keterkaitan di antara stasiun kerja [8]. Adapun kriterianya adalah ditunjukkan pada Tabel VI.

TABEL VI

$$
\text { KRITERIA KEDEKATAN }
$$

\begin{tabular}{|c|l|}
\hline No & \multicolumn{1}{|c|}{ Alasan } \\
\hline 1 & Urutan proses produksi \\
\hline 2 & Jarak minimum perpindahan material \\
\hline 3 & Kemudahan dalam pemeriksaan \\
\hline 4 & Pekerjaan serupa \\
\hline
\end{tabular}

Melalui kriteria kedekatan, dapat ditentukan derajat keterkaitan antar stasiun kerja. Gambar 5 menunjukkan ARC dari fasilitas lantai produksi pada CV. ABC Offset.

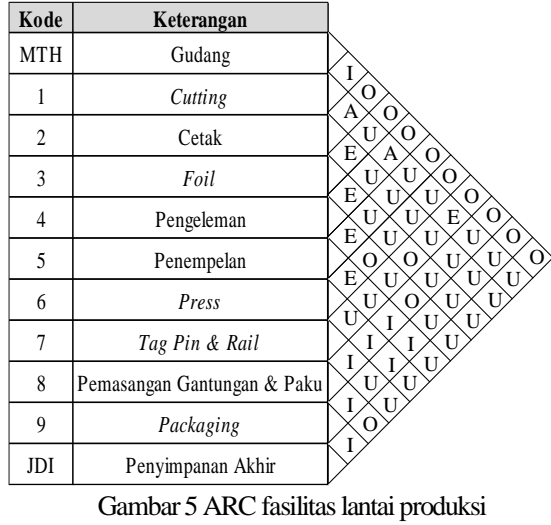

b. Membuat area allocation diagram (AAD)

AAD dibuat untuk mengetahui stasiun mana yang letaknya berdekatan dan stasiun mana yang letaknya berjauhan sesuai dengan ARC. Gambar 6 menunjukkan AAD pada lantai produksi.

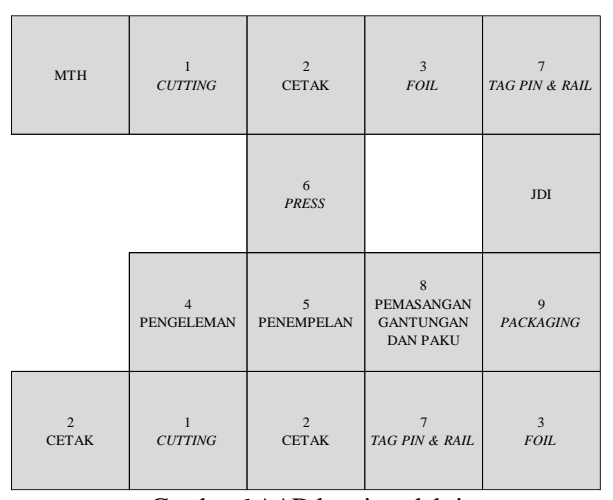

Gambar 6 AAD lantai produksi

c. Menentukan titik pusat

Dari matriks elemen layout yang telah dibuat, dapat dihitung jarak antar stasiun. Akan tetapi, sebelum melakukan perhitungan jarak antar stasiun perlu ditentukan titik pusat (centroid) dari setiap stasiun kerja. Tabel VII merupakan hasil perhitungan centroid dalam satuan $\mathrm{m}^{2}$.

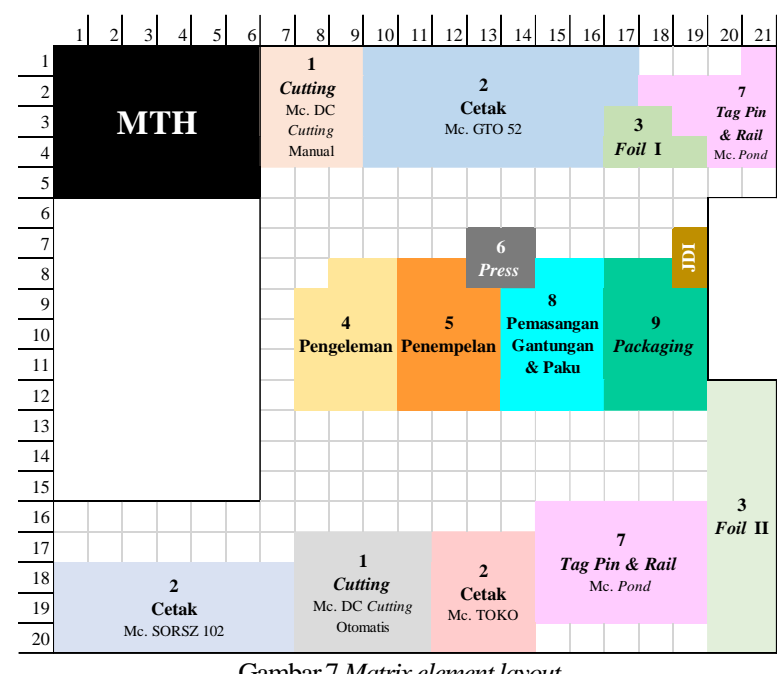

Gambar 7 Matrix element layout 
TABEL VII

TITIKPUSAT SETIAP STASIUN KERJA

\begin{tabular}{|c|c|c|c|}
\hline Stasiun & Jenis Peralatan/Mesin & X & Y \\
\hline MTH & & 3 & 2.5 \\
\hline \multirow{3}{*}{ Cutting } & Mc. DC Cutting Manual & 7.5 & 2 \\
\cline { 2 - 4 } & $\begin{array}{c}\text { Mc. DC Cutting } \\
\text { Otomatis }\end{array}$ & 9 & 18 \\
\hline \multirow{3}{*}{ Cetak } & Mc. GTO 52 & 13 & 2.5 \\
\cline { 2 - 4 } & Mc. SORSZ 102 & 3.5 & 18.5 \\
\cline { 2 - 4 } Foil & Mc. TOKO & 12.5 & 18 \\
\hline Mengeleman & Mc. PolarI & 17.5 & 3 \\
\hline Penempelan & Meja & 20 & 15.5 \\
\hline Press & Meja & 8.5 & 9.5 \\
\hline Tag Pin \& Rail & Besi Press & 11.5 & 9.5 \\
\hline Pemasangan & Mc. Pond & 13 & 7 \\
\hline Gantungan \& Paku & Meja & 14.5 & 17 \\
\hline Packaging & Meja & 17.5 & 9.5 \\
\hline JDI & Rak & 18.5 & 7 \\
\hline
\end{tabular}

d. Perbandingan jarak antar stasiun kerja saat ini dan usulan

Setelah mendapatkan titik pusat pada setiap stasiun kerja, selanjutnya adalah menghitung jarak antar stasiun. Jarak akan dihitung dengan perhitungan jarak rectilinear. Setelah itu, dilakukan perbandingan jarak antar stasiun kerja saat ini dan usulan. Tabel VIII menunjukkan perbandingan jarak stasiun kerja saat ini dan usulan

TABEL VIII

PERBANDINGAN JARAK ANTAR STASIUN KERJA SAAT INIDAN USULAN

\begin{tabular}{|c|c|c|c|}
\hline Dari & Ke & $\begin{array}{c}\text { Jarak } \\
\text { Saat ini } \\
(\mathbf{m})\end{array}$ & $\begin{array}{c}\text { Jarak } \\
\text { Usulan } \\
(\mathbf{m})\end{array}$ \\
\hline MTH & $\begin{array}{c}\text { Cutting (Mc. DC } \\
\text { CuttingManual) }\end{array}$ & 21.5 & 5 \\
\hline $\begin{array}{c}\text { Cutting (Mc. DC } \\
\text { CuttingManual) }\end{array}$ & $\begin{array}{c}\text { Cetak (Mc. GTO } \\
\text { 52) }\end{array}$ & 19.5 & 6 \\
\cline { 2 - 4 } & Pengeleman & 17 & 8.5 \\
\hline $\begin{array}{c}\text { Cetak (Mc. GTO } \\
\text { 52) }\end{array}$ & Foil (Mc. Polar I) & 16 & 5 \\
\hline Foil (Mc. Polar I) & Penempelan & 10.5 & 12.5 \\
\hline Penempelan & Press & 3 & 4 \\
\hline Press & $\begin{array}{c}\text { Cutting (Mc. DC } \\
\text { CuttingManual) }\end{array}$ & 14 & 10.5 \\
\hline $\begin{array}{c}\text { Cutting (Mc. DC } \\
\text { CuttingManual) }\end{array}$ & Tag Pin \& Rail & 8.5 & 11.5 \\
\hline $\begin{array}{c}\text { Tag Pin \& Rail } \\
\text { Pemasangan } \\
\text { Paku }\end{array}$ & 15.5 & 12 \\
\hline $\begin{array}{c}\text { Pemasangan } \\
\text { Gantungan \& } \\
\text { Paku }\end{array}$ & $\begin{array}{c}\text { Packaging } \\
\text { Tackaging }\end{array}$ & 1 & 3 \\
\hline Total Jarak Tempuh & 126.5 & 81.5 \\
\hline Jang & 1 & 3.5 \\
\hline
\end{tabular}

Melalui Tabel VIII, dapat diketahui bahwa setelah dilakukan perbaikan tata letak stasiun kerja, terjadi pengurangan jarak antar stasiun kerja, dimana pada kondisi saat ini total jarak tempuh adalah 126,5 meter dan pada kondisi usulan adalah 81,5 meter. Dengan berkurangnya jarak antar stasiun kerja maka dapat mengurangi waktu tunggu pemindahan material antar stasiun kerja.
2. Perbaikan desain besi press

Untuk dapat menghilangkan aktivitas menunggu, maka perusahaan dapat memperbaiki desain besi press hingga berkapasitas 200 buah untuk satu kali proses.

3. Membuat tempat penyimpanan scrap sementara

Jalur operator dan trolley atau handtruck yang terhalang oleh tumpukan sisa material dapat dihilangkan dengan cara membuat tempat sisa material sementara, baik pada stasiun kerja maupun di luar area lantai produksi sebelum diangkut oleh pemborong. Karena minimnya area pada lantai produksi, tempat penyimpanan sementara berukuran besar sebaiknya diletakkan di luar area lantai produksi agar tidak menghalangi jalur trolley atau handtruck. Gambar 8 menujukkan tempat scrap pada stasiun kerja (tempat scrap kecil) dan Gambar 9 menunjukkan tempat scrap diluar lantai produksi (tempat scrap besar).

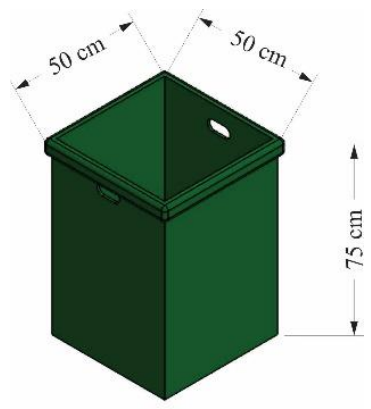

Gambar 8 Desain tempat scrap kecil

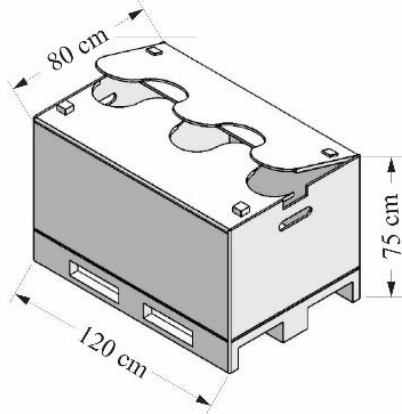

Gambar 9 Desain tempat scrap besar
4. Menyediakan rak penyimpanan

Dari usulan perbaikan tata letak fasilitas lantai produksi, tentunya terdapat perubahan yang terjadi, salah satunya adalah dengan dibuatnya area penyimpanan sementara produk jadi sebelum dikirim ke customer. Selain itu, area penyimpanan campuran yang digunakan untuk menyimpan berbagai macam barang, seperti kertas sisa potong yang masih bisa dipakai hingga barang yang tidak terpakai akan pindah setelah dilakukan perbaikan akan dijadikan stasiun cutting, sehingga dibutuhkan area penyimpanan yang baru. Oleh karena itu, pada area penyimpanan produk jadi dan area penyimpanan kertas sisa potong yang masih bisa dipakai dibuat rancangan rak sebagai tempat penyimpanan. Gambar 10 menunjukkan desain rak.

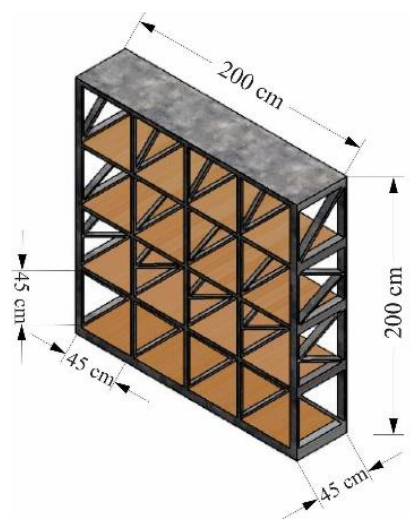

Gambar 10 Desain rak 
5. Layout usulan

Berdasarkan usulan-usulan di atas, maka dibuatlah gambar layout usulan yang memuat keseluruhan usulan di dalamnya. Gambar 11 merupakan gambar layout usulan lantai produksi CV. ABC Offset.

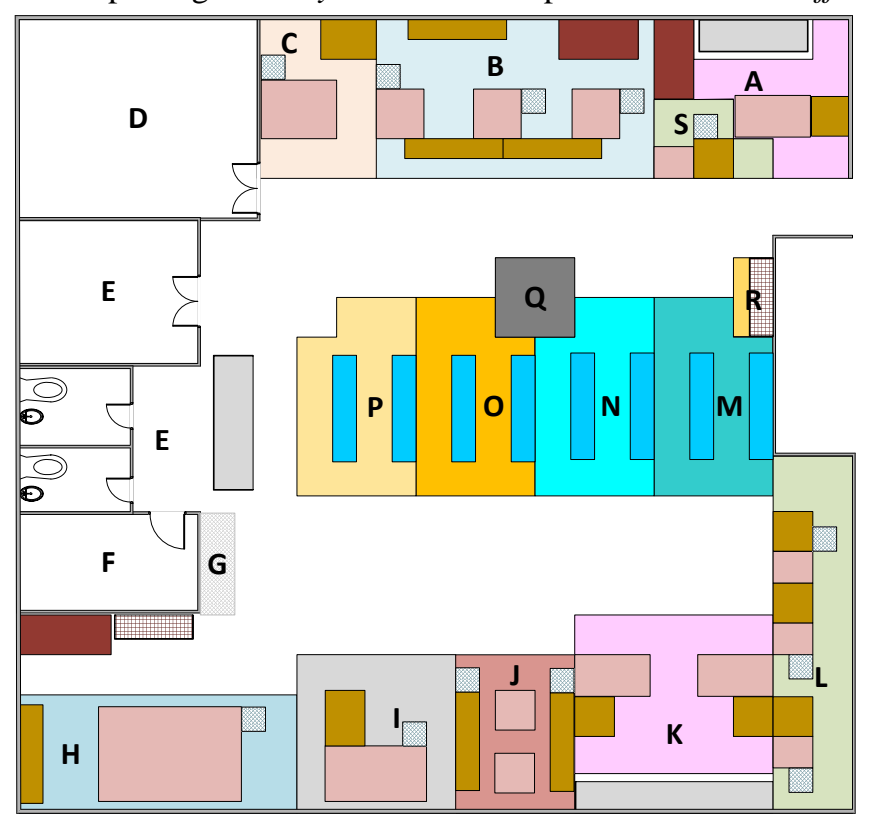

Gambar 11 Layout usulan lantai produksi CV. ABC Offset

Keterangan

\begin{tabular}{|c|c|c|c|c|c|}
\hline A & $:$ & $\begin{array}{l}\text { Stasiun Tag Pin \& Rail } \\
\text { (Mc. Pond) }\end{array}$ & $\mathrm{N}$ & : & $\begin{array}{l}\text { Stasiun Pemasangan } \\
\text { Gantungan \& Paku (Area } \\
\text { Finishing) }\end{array}$ \\
\hline B & $:$ & $\begin{array}{l}\text { Stasiun Cetak (Mc. } \\
\text { GTO 52) }\end{array}$ & $\mathrm{O}$ & . & Stasiun Penempelan \\
\hline $\mathrm{C}$ & $:$ & $\begin{array}{l}\text { Stasiun Cutting (Mc. } \\
\text { DC Cutting Manual) }\end{array}$ & $\mathrm{P}$ & & Stasiun Pengeleman \\
\hline $\mathrm{D}$ & $:$ & Gudang Bahan Baku & Q & : & Stasiun Press \\
\hline $\mathrm{E}$ & $:$ & $\begin{array}{l}\text { Toilet dan Kamar } \\
\text { Mandi }\end{array}$ & $\mathrm{R}$ & . & $\begin{array}{l}\text { Penyimpanan Sementara } \\
\text { Produk Jadi }\end{array}$ \\
\hline $\mathrm{F}$ & $:$ & Gudang Tinta & $\mathrm{S}$ & : & Stasiun Foil (Mc. Polar) \\
\hline G & $:$ & Musholla & & • & Penyimpanan WIP \\
\hline $\mathrm{H}$ & $:$ & $\begin{array}{l}\text { Stasiun Cetak (Mc. } \\
\text { SORSZ 102) }\end{array}$ & & . & Mesin \\
\hline I & $:$ & $\begin{array}{l}\text { Stasiun Cutting (Mc. } \\
\text { DC Cutting Otomatis) }\end{array}$ & & & Meja \\
\hline $\mathrm{J}$ & $:$ & $\begin{array}{l}\text { Stasiun Cetak (Mc. } \\
\text { Toko) }\end{array}$ & & . & Rak Plate \\
\hline $\mathrm{K}$ & $:$ & $\begin{array}{l}\text { Stasiun Tag Pin \& Rail } \\
\text { (Mc. Pond) }\end{array}$ & & : & Rak \\
\hline $\mathrm{L}$ & . & & 政 & . & Tempat penyimpanan \\
\hline & & $\begin{array}{l}\text { Stasiun Foil (Mc. } \\
\text { Polar) }\end{array}$ & & & scrandi staciun keri \\
\hline M & : & $\begin{array}{l}\text { Stasiun Packaging } \\
\text { (Area Finishing) }\end{array}$ & E & : & Rak penyimpanan usulan \\
\hline
\end{tabular}

E. Value Stream Mapping future state

Berdasarkan usulan perbaikan guna mengatasi akar penyebab yang ada, maka dipetakan alur produksi hanger sample dengan menggunakan value stream mapping future state. Melalui VSM future state, diketahui bahwa terjadi pengurangan waktu pemindahan material antar stasiun kerja, salah satnya pada stasiun cutting ke stasiun cetak, dimana waktu siklus saat ini adalah 613,27 detik menjadi 188,7 detik. Gambar VSM future state dapat dilihat pada Lampiran.

\section{KESIIMPULAN}

Berdasarkan hasil pengolahan data kuesioner yang disebarkan kepada manajer produksi dan operator yang mengerjakan pembuatan hanger sample serta hasil observasi yang dilakukan, terjadi waste waiting pada proses pembuatan hanger sample di CV. ABC Offset. Setelah dilakukan identifikasi dan analisis penyebab waste dengan menggunakan tools, yaitu fishbone diagram, pareto diagram, dan 5 whys, dapat diketahui bahwa waste waiting yang terjadi disebabkan oleh 3 penyebab dominan, yaitu adanya proses menunggu selama 3 jam pada stasiun press yang disebabkan oleh kurangnya kapasitas besi press yang digunakan pada saat proses press, terjadinya excessive travel dikarenakan jarak perpindahal material yang cukup jauh dan dilakukan secara berkali-kali karena material diangkut oleh operator tanpa menggunakan material handling, dan terhalangnya jalur trolley dan handtruck karena terhalang oleh tumpukan material yang disebabkan tidak adanya tempat penyimpanan sementara sehingga operator memindahkan material secara manual. Adapun beberapa usulan perbaikan diberikan untuk dapat meminimasi pemborosan yang terjadi, yaitu perbaikan tata letak stasiun kerja untuk mengurangi waktu tunggu pemindahan material antar stasiun kerja, perbaikan desain besi press berkapasitas 200 buah, serta menyediakan tempat penyimpanan material sementara dan tempat penyimpanan scrap sementara pada stasiun kerja.

\section{DAFTAR PUSTAKA}

[1] A. Merici, Perancangan Perbaikan Area Permesinan Komponen Isolating Cock di PT. Pindad (Persero) untuk Meminimasi Waste Menggunakan Metode 5S dengan Pendekatan Lean Manufacturing, Bandung: Telkom University, 2015.

[2] R. Charron, H. J. Harrington, F. Voehl and H. Wiggin, The Lean Management System Handbook, Boca Raton: CRC Press, 2015, p. 327.

[3] V. Gaspersz, Lean Six Sigma for Manufacturing and Service Industry, Jakarta: Gramedia, 2011.

[4] B. Wijayanto, A. Saleh and E. Zaini, "Rancanga Proses Produksi untuk Mengurangi Pemborosan dengan Penggunaan Konsep Lean Manufacturing di PT. Mizan Grafika Sarana," Jurnal Online Institut Teknologi Nasional, vol. 3, pp. 119 - 130, 2015.

[5] Q. Kusuma, P. P. Suryadhini and M. Rahayu, "Rancangan Usulan Perbaikan untuk Meminimasi Waste Waiting pada Proses Produksi Rubber Step Aspira Belakang dengan Pendekatan Lean Manufacturing (Studi Kasus: PT. Agronesia Divisi Industri Teknik Karet)," Jurnal Rekayasa dan Sistem Industri, vol. 3, pp. $52-61,2016$.

[6] W. Waiyaratn and A. Watanapa, "Improvement Plant Layout using Systematic Layout Planning (SLP) for Increased Productivity," International Journal of Mechanical, Aerospace, Industrial, Mechatronic and Manufacturing Engineering, vol. 4, pp. 1382 - 1386, 2010.

[7] T. Yang, C. T. Su and Y. R. Hsu, "Systematic Layout Planning: A Study on Semiconductor Wafer Fabrication Facilities," International Journal of Operations Product Management, vol. 20, pp. 1359 - 1371, 2000.

[8] J. M. Apple, Tata Letak Pabrik dan Pemindahan Bahan, Bandung: ITB, 1990. 
Lampiran A. Value Stream Mapping Current State

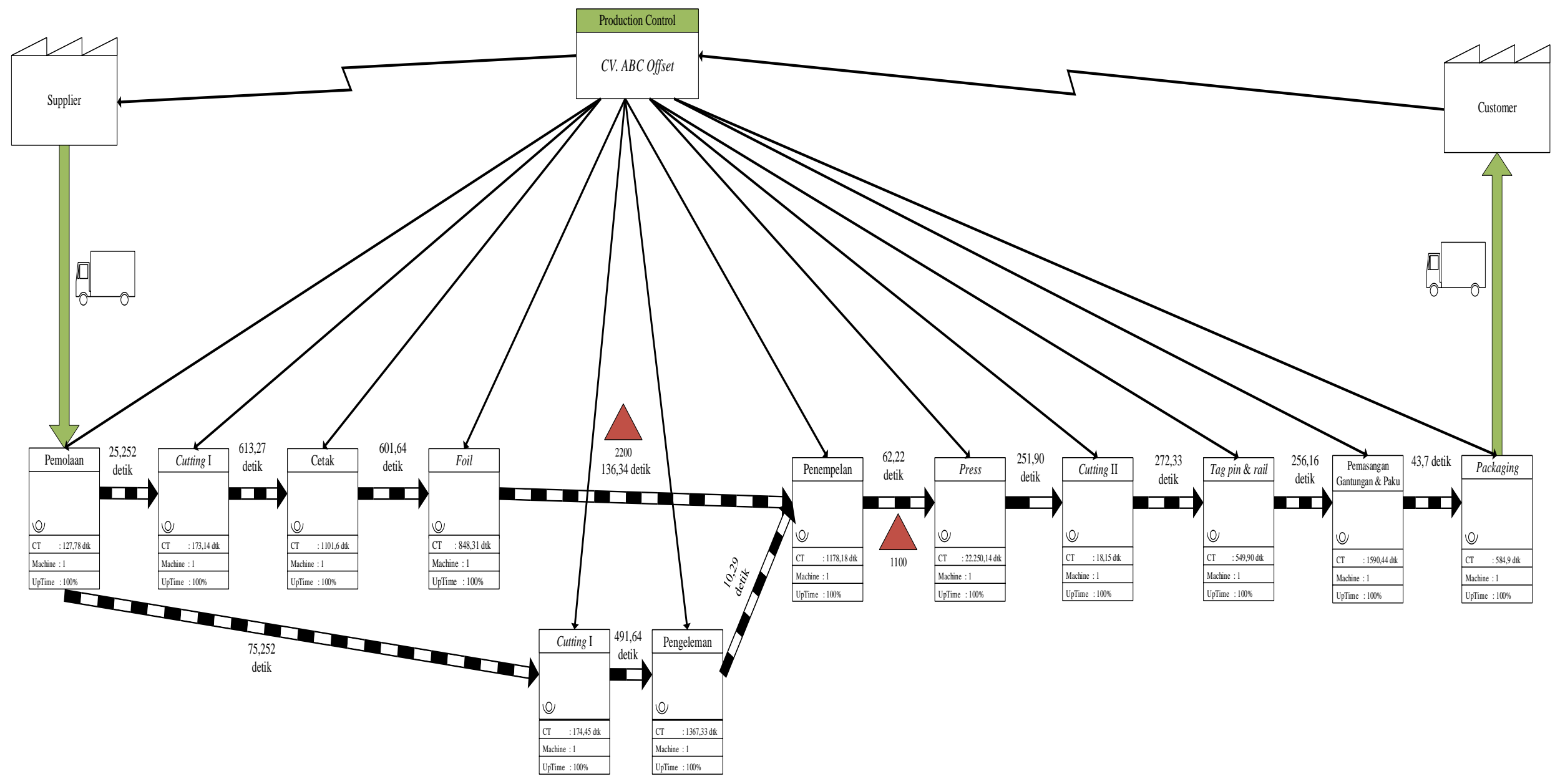

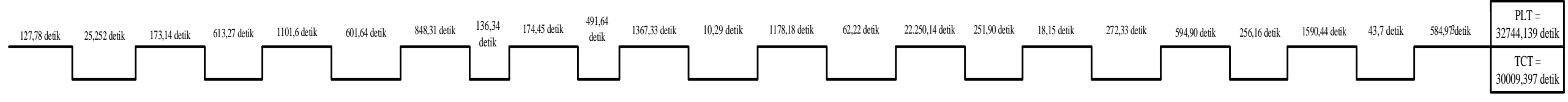




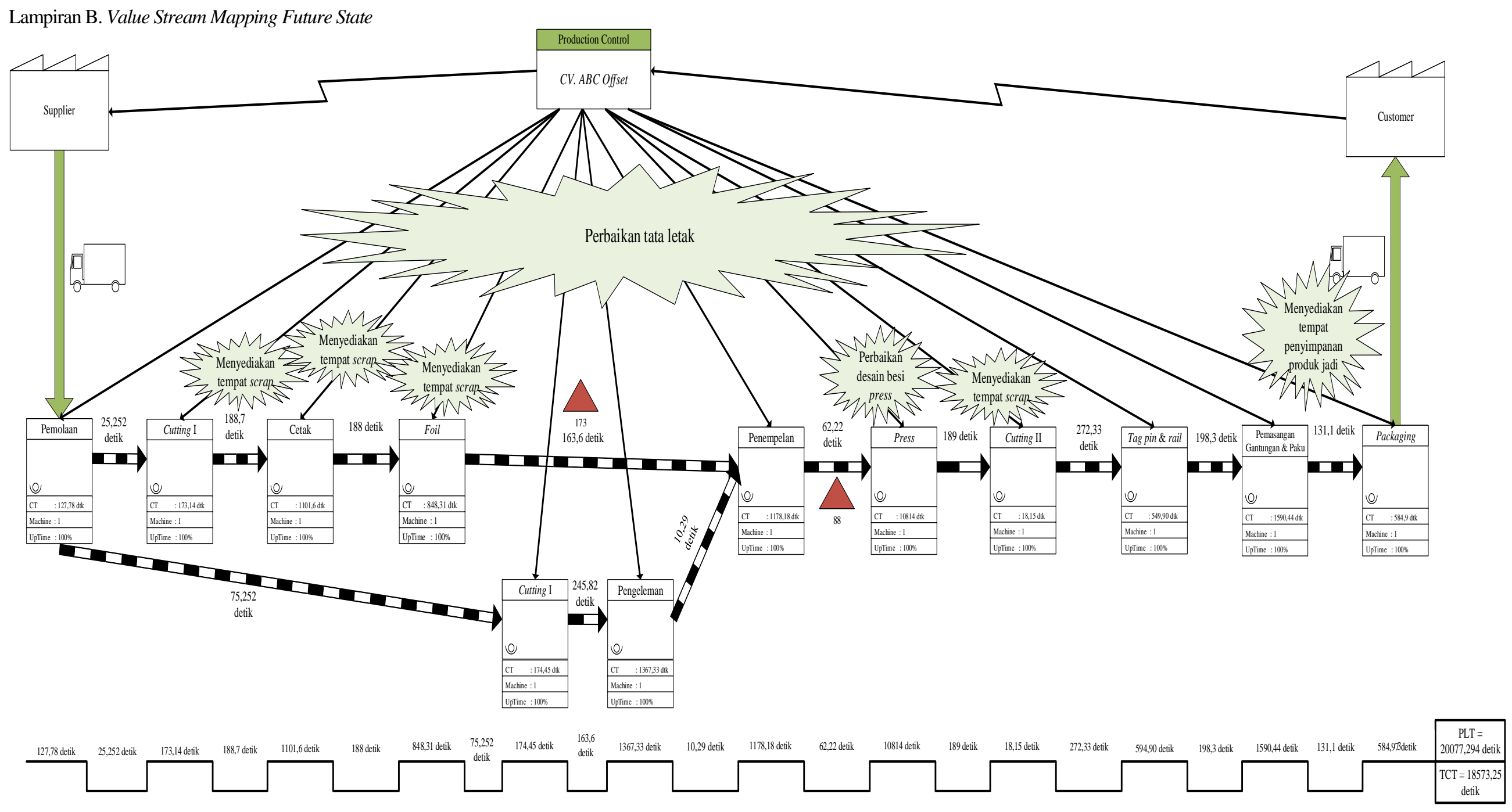

